\title{
The Problem of Forming an Effective System of Regulation of World and National Economy
}

\author{
Andrei Kharlamov \\ St. Petersburg State University of Economics \\ Saint-Petersburg, Russia \\ E-mail: Kharlamov_2000@list.ru
}

\author{
Tatyana Kharlamova \\ Peter the Great St. Petersburg Polytechnic University \\ Saint-Petersburg, Russia \\ E-mail: Kharlamova_t@list.ru
}

\begin{abstract}
The contemporary stage of development of world economy is characterized by constantly emerging financial crises that requires to use some new instruments for their suppression. The basis for the application of such instruments is the formation an effective system of regulation of the economy. It is aimed at the enhancement of the role and importance of supranational regulation, while increasing the effectiveness of state regulation. Moreover, the state regulation should be built into the system of global regulation to ensure the interests of different economic entities on the basis of national priorities. This design will allow to solve numerous significant problems at the global and national levels and to ensure the dynamic development of national and world economy. It is based on the opportunities provided by the Internet technologies and the involvement of a wide range of citizens who are not indifferent to the economic development of their country.
\end{abstract}

Keywords — world economy; national economy; globalization; economic crises; management system; new managerial technologies; effectiveness of state regulation

\section{INTRODUCTION}

Currently, we can see a process of reinforcing factors influencing the decline of stability in the global economy. It affects not only on the separate countries but also on the process of globalization. The series of indicators show that existence of many large and medium-sized regional centers soon will become the norm. At the same time the political interests and technological factors will strengthen their influence on the economic development.

It is obvious that the formation of a new economic system will take a long time, but the direction of the current changes can be seen today. This doesn't mean that all the coming changes are already clear. Of course, some changes will occur quickly, and some slowly. It would create the contradictions in the interests of various countries, especially those that develop faster than the others. In this situation the process of formation of regional powers is growing with considering of economic, technological and also political influence. Furthermore, it determines the theoretical and practical interest to the analysis of the actions that countries should undertake to prevent the deepening of contradictions. It would reduce the degree of economic risks and minimize their negative impact on individual countries, groups of countries and all global community.

\section{The NeCESSITY OF BUILDING AN EFFECTIVE SysteM OF INTERNATIONAL ECONOMIC REGULATION}

Speaking about the results of the structural displacements in the global economy in 2008-2009, we can see that they have led to significant changes in the nature of its functioning. For three decades prior to that an active process of globalization of financial markets was started. It significantly expanded the scale of the transfer of capital from country to country and created numerous difficulties with regulation, especially in taxation system. This required from national governments a great attention to international financial institutions, compared to national producers of goods and services. International financial institutions became more privileged in relation to the national players that reflected in a change in the proportions in the structure of national economies of host countries.

This situation was not acceptable to the national governments of developing countries. It demanded theoretical rethinking the construction of the world economy. However, the growing dissatisfaction of small economies caused resistance from the international financial institutions, primarily - transnational corporations. Their power was allowed to change the economy of host countries, making it dependent on their economic and political interests, as evidenced by the results of presidential elections in these countries [1].

The changes that have occurred in recent years increased the instability of the financial system. It could be estimated as a failure of monetarism. The modern practice shows that financial markets are not able to effectively regulate not only the economy as a whole, but also themselves; this is confirmed by series of global financial crises. Today many experts in various circles - business, scientific and political believe that all future crises will only financial [2].

In these conditions the modern science should examine the necessity of changing the current order of regulation of financial markets and financial institutions and creating a single mechanism for financial regulation with supranational character. It would correct the order according to which the national governments operate in the economic interests of 
their own countries and their actions promote protectionism in all sectors of national manufacturing. However, the design of financial market in the period of globalization cannot be regulated in this way; it requires supranational regulation relevant to all participants of the global economic space. Otherwise, the stability of the global financial market could be undermined. It will have a negative impact on all spheres of economic activities at the level of global and national economies [3]. It must be said that the implementation the idea of creating a supranational regulation becomes much more complicate with the advent of cryptocurrency.

The emergence and promotion of the cryptocurrency, as a result of development of information economy, affects the basis of existence of the modern world - its financial system. Currently, this problem has attracted a lot of attention of serious scientists, politicians, businessmen, especially operating in the banking business and mass media. [4]. If the original the cryptocurrency was perceived as a technological experiment, then - as a dangerous tool of the shadow and illegal economy, and even the financing of global terrorism, now we hear that it is - a future which is impossible to ignore. This confirms the experience of Japan, where such currency has the status of a means of payment from April 2017 , while the yen remains the official currency of this country [5]. But despite so rapid development of cryptocurrency its future and stability are not clear. Now the global financial system is on the threshold of significant changes that individual governments couldn't control. Therefore, we must look for other effective instruments for regulating this process

The movement to unified international regulation faces serious challenges, evidenced by the problems in the financial market, as well as recent events in the European Union, including Brexit. At the same time, the countries implementing economic policies oriented to maximum assistance to domestic producers achieve notable successes today. The absolute record belongs to Holland, whose economy has developed rapidly from 1981 to 2008 . Australia demonstrates the progress also; the main important result of this country is twenty-five "anniversary" of life without recession. Even in the period of the global crises in 1998 and 2008 the country held its positions, continuing to provide positive economic growth. The Australian economy has withstood a period of decline in prices on energy and raw materials, despite these markets are traditionally significant to this country. The reasons of that are the next: choosing the correct set of priorities, detailed account of the interests of national business and a smart system of state regulation of the economy. So, in the period of the global financial crisis of 2008 (which was so painful for the Russian economy) the government of Australia supported the construction industry and public investment for keeping positive rates of economic growth [6]. We should note that the economic successes of this country allow it to strengthen political position in the region and in the world as a whole.

In this regard, the process of building an effective international system of regulation should be combined with the regulation at the national level.

\section{IMPROVEMENT OF THE NATIONAL ECONOMIC REGULATION AS A NECESSARY CONDITION FOR THE FORMATION OF THE WORLD SYSTEM OF REGULATION}

The construction of an effective system of state regulation of economy is an essential component of the international regulatory system. It should be noted that the state, which poorly protects the interests of national economic entities is unable to effectively influence the processes of global development. The decisions of world regulatory institutions often reflect the interests of the economically strong countries at the expense of the rest. This statement could be proved by the examples of some decisions of WTO.

Let's consider the most important problems to be solved in the framework of the national regulation of the economy considering the activities of international business entities operating in the territory of a particular country.

\section{A. Determination of the Place of the Country in the Global Economy}

As mentioned above, the successful state of the modern type must have all the characteristics of economic and technological power. This implies a creation of the relevant economic system, receptive to new technologies, able to generate innovations and influence the course of world development.

In the context of defining the priority directions of innovative process we need to be aware of global trends and to analyze the signals emerging in the world information space. So, recently in the UK it was decided to refuse from the use of internal combustion engines. The UK government announced the transition to vehicles running on electricity from 2040 [7]. This country is not alone in such decision now. This raises a question: what should do our domestic enterprises in this situation? Today we can see a number of successful projects of construction high-speed tracks in such countries as Japan, China and the USA. It's necessary to estimate all possible effects of these projects for the world market and environment. Of course, no one is questioning the fact that natural resources, including land, water, air, energy resources, metals, will continue to retain their importance for economy. But their role wouldn't be absolute. It means the need for increased support of science and education and improvement the quality of human capital as an essential condition of existence an economic and technological power.

\section{B. Identifying the Major Challenges for the World Economy}

- This group of problems includes some events associated with growing process of formation a multipolar world. The process affects not only the economic but also the political system and it cannot be painless. If even 5-10 years ago we said about the appearance of three world powers - the USA, European Union and China, at the present time we can see the tendency of expanding this list. It is due not only to the inclusion new countries in it but also 
to a new understanding the meaning of such centers, more precisely - their division on levels [8]. This is manifesting in the redistribution of markets and spheres of influence, as well as holding a more active foreign policy by several states, including the elements of pressure.

In addition, the situation of global economic instability is accompanied by the growth of terrorist threats practically in all regions of the world, even those that were quite prosperous and tolerant previously.

- The most important global challenges are associated with modern technological changes. We can say with confidence that today the world is on the threshold of a new technological revolution with numerous transformations in the structure of the world economy. They are related to the emergence of innovative technologies and means of production, significantly increasing productivity and reducing production costs (for example - the shale revolution).

- The transformation in the labor market and in the social sphere will be following important dislocation. Already today the processes of customization and personalization of production and consumption are strengthening. The product (good or service) is created not in a mass scale, but on the base of its value for specific groups of consumers. It is possible thanks to the rapid development of modern technologies, especially information, which provides a high degree of adaptability of goods and services and their maximum approximation to the consumers. As a rule, the individualization of production is successfully implemented in the framework of a small, innovation-focused companies and startups. To define these processes, we use the term "crafting economy". Its essence is the decrease in the share of large firms producing final goods for households and the proliferation of different personal services and digital technologies.

\section{Reformation in a Sphere of Public Administration}

The objective function of such reformation is the building a system corresponding to the conditions of globalization and able to answer adequately to all its challenges. A new system should be mobile to provide high efficiency of public administration without significant budget costs. The problem of efficiency of public administration is relevant to all countries both economically developed and developing. This issue can be considered today as a global [9].

Based on domestic and international practice, we could regard the presence of a large number of officials like an indirect indicator of insufficient efficiency of public administration due to the availability of overlapping functions and low speed for decision-making.

It is very difficult to search the model of new design of state regulation and administration system. There are several fundamental reasons of that, as discussed above. We couldn't reasonably speak about further steps in this direction until implementation of a number of strategic actions. But now we can use new technological solutions in the administrative system, actively involving the capabilities of the wide masses of citizens.

\section{NEW TECHNOLOGIES IN THE SySTEM OF MANAGEMENT OF ECONOMY}

The central place among the technologies of management belongs to the global Internet technologies and the tool of crowdsourcing [10]. It operates through the engaging the intellectual capabilities of a wide range of individuals and allows to identify problems and to develop a mechanism for their solutions on a voluntary basis. We can understand crowdsourcing acts as a "collective mind" in a process of solving relevant management tasks. This way determines the development of public administration system in advanced countries now.

Thus, the effective model of state management system using the capabilities of crowdsourcing will look like a set of recurring actions within the framework of five basic units.

- Unit 1. Identifying the priorities, differing in level (strategic, operational and tactical) and scale (international, national, regional, municipal), reflecting the interests of the most of citizens.

- Unit 2. Creating a pool of professional executors (corporate and individual). In some cases, key functions can be imposed not on the official but on the person enjoying the special confidence among the colleagues, citizens and others. This gives the opportunity for implementation of collective approach to determining a set of skills and human qualities of effective manager. Gratuitous nature of crowdsourcing allows administrative institutions to engage people with the high level of needs and interests: in communication, implication, recognition and self-realization. For some of them it is a chance to improve the life in separate district, city, village, and for others - a way to express themselves, making thereby the first steps towards a future managerial career.

- Unit 3. Definition of criteria and indicators for estimation the efficiency of management decisions. We can determine the most appropriate benchmarks, indicators, evaluation tools and directions of communication with the state and society only in the process of joint discussions with the participation of a wide range of stakeholders and experts.

- Unit 4. Building an effective mechanism for the solution problems formulated in the framework of the first unit. The applying of "collective mind" will allow to minimize errors in the acts of the executive bodies of state power, as well as experts and lobbyists. Monitoring of expenses will be provided through the use of modern Internet technologies. 
- Unit 5. Evaluation obtained results, including the efficiency of the state management, and organization of effective feedback. These actions should become the important components of improving the system of public administration on the basis of transparency and removability [11].

In our opinion, the widespread introduction of crowdsourcing will have a positive impact on all spheres of activities, ensuring support and promotion of economic development in a particular area and in the country as a whole. Also, it will provide a positively influence on the functioning the regulatory system on a basis of consideration all economic and non-economic interests of people.

\section{CONCLUSION}

The changes happening in the global economy have an increasingly significant impact on the economy system of every country, regardless of its scale and level of development. This effect involves the creation of a management system for the most efficient use of opportunities providing by the global economy.

The processes currently taking place in the world economy point to the need for joint efforts by all countries in improving the system of regulatory institutions. The most significant problems we can see in the global financial market. A lot of facts show that they cannot be solved independently by any one national government. Furthermore, the problems in the financial market often provoke the development of the world economic crises. In this regard, there is urgent need of creating a system of international regulatory institutions. Such system, on the one hand, will prevent mechanisms and tools for restraining various "failures" in global financial markets and, on the other hand, will provide inducement for further development.

The presence of well-functioning international governing institutions does not necessitate the weakening of the action of regulatory institutions at the national level. On the contrary, the role of the public administration system should be modified to increase. This strengthening should be carried out on a number of fronts:

- To ensure the adaptability in the global regulatory system for satisfying a complex of national and global interests;

- To protect the national economic if the interests of other countries or their coalitions are contrary to the national interests;

- To carry out a policy of modernization of the management system, making it adequate to the addressed relevant tasks;

- To use new technologies and tools in the management system, both technological and informational;

- To involve citizens to solution of management problems, especially at the stages of implementation of the tasks and assess their results, for satisfaction the interests of people.
All the above can be considered as a basis for changing the approach to the building the system of global and national regulation. However, any action must be carefully thought out and prepared in material, financial, technological and intellectual terms. As a result, the regulatory system must become effective and more adequate to the tasks not only in a sphere of economy but in other spaces of modern world.

\section{REFERENCES}

[1] P. Neumann, The Impact of Structural Changes in National Economies on Globalization Character, Proceedings of the 15th International Scientific Conference on Globalization and Its SocioEconomic Consequences, Part II, Zilina, Slovakia, pp. 498-504, October 2015.

[2] Paul Welfens, Transatlantisches Freihandelsabkommen EU-USA Befunde zu den TTIP-Vorteilen und Anmerkungen zur TTIP-Debatte / https://econpapers.repec.org/paper/bwueiiwdp/ disbei209.htm.

[3] The Soros Lectures at the Central European University (Public Affairs, 2010) / https://www.georgesoros.com/wpcontent/uploads/2017/10/the_soros_lectures-open_society2017_10_05.pdf.

[4] What are the risks of Bitcoin? / https://www.quora.com/What-are-therisks-of-Bitcoin

[5] I. Ajzyatulova, Australian stability, Electronic resource https://www.gazeta.ru/business/2016/09/10/10186643.shtml

[6] I.V. Kolosov, Economic outlooks for shale gas extraction on the background of the energy resources prices' dropping // Discussion. № 4 (78), pp. 29-35, April, 2017.

[7] V.G. Baranovsky, Transformation of Global World Order: Dynamics of Systemic Changes” // Polis. Political Studies. 2017. № 3. pp. 71-91.

[8] O.V. Kiselkina, A.V. Kharlamov, T.L. Kharlamova, A.F. Vunotropidi, The increasing of quality requirements of state regulation of economy in solving of social tasks, Social Sciences and Interdisciplinary Behavior: The Proceedings of the 4th international congress on interdisciplinary behavior and social sciences, ICIBSOS 2015. Edited by Ford Lumban Gaol, Fonny Hutagalung, Bagautdinova Nailya, Safiullin Lenar, 2016, pp. 425-427.

[9] Analysis of factors affecting the implementation of strategic planning documents at the highest level, Analytical report. / http://csr.ru/wpcontent/uploads/2016/12/Report-on-strategy.pdf.

[10] A.V. Kharlamov, T.L. Kharlamova, The security of the Russian economy and development of management of the business environment in the conditions of global instability, News of the Tula state university. Economic and legal sciences. 2014, Issue 5, pp. 3441.

[11] A.V. Kharlamov, Development of Russia in the conditions of global economic instability // Izvestiya of Saratov University. New series. Series: Economics. Management. Law", 2018. № 1. pp. 4-11. 